\title{
norden
}

Nordsyn - ecodesign and energy labelling requirements for oil- and gas-fired boilers

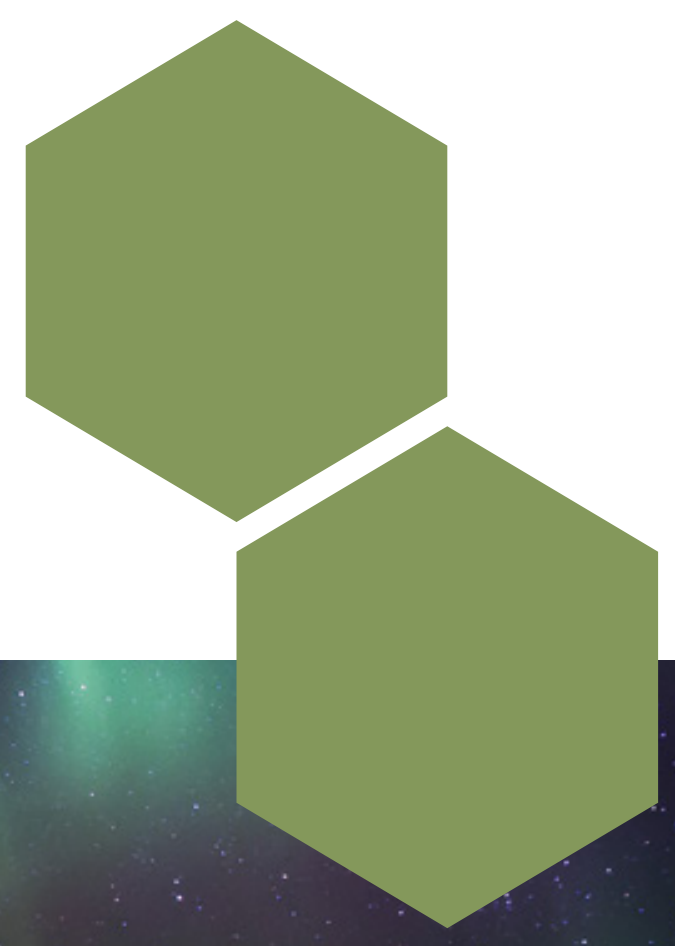

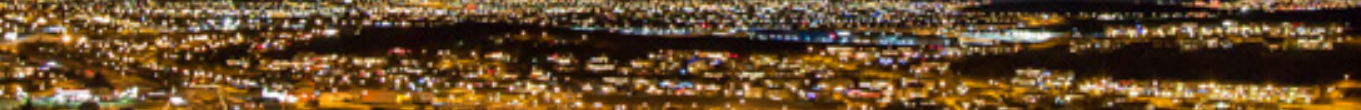
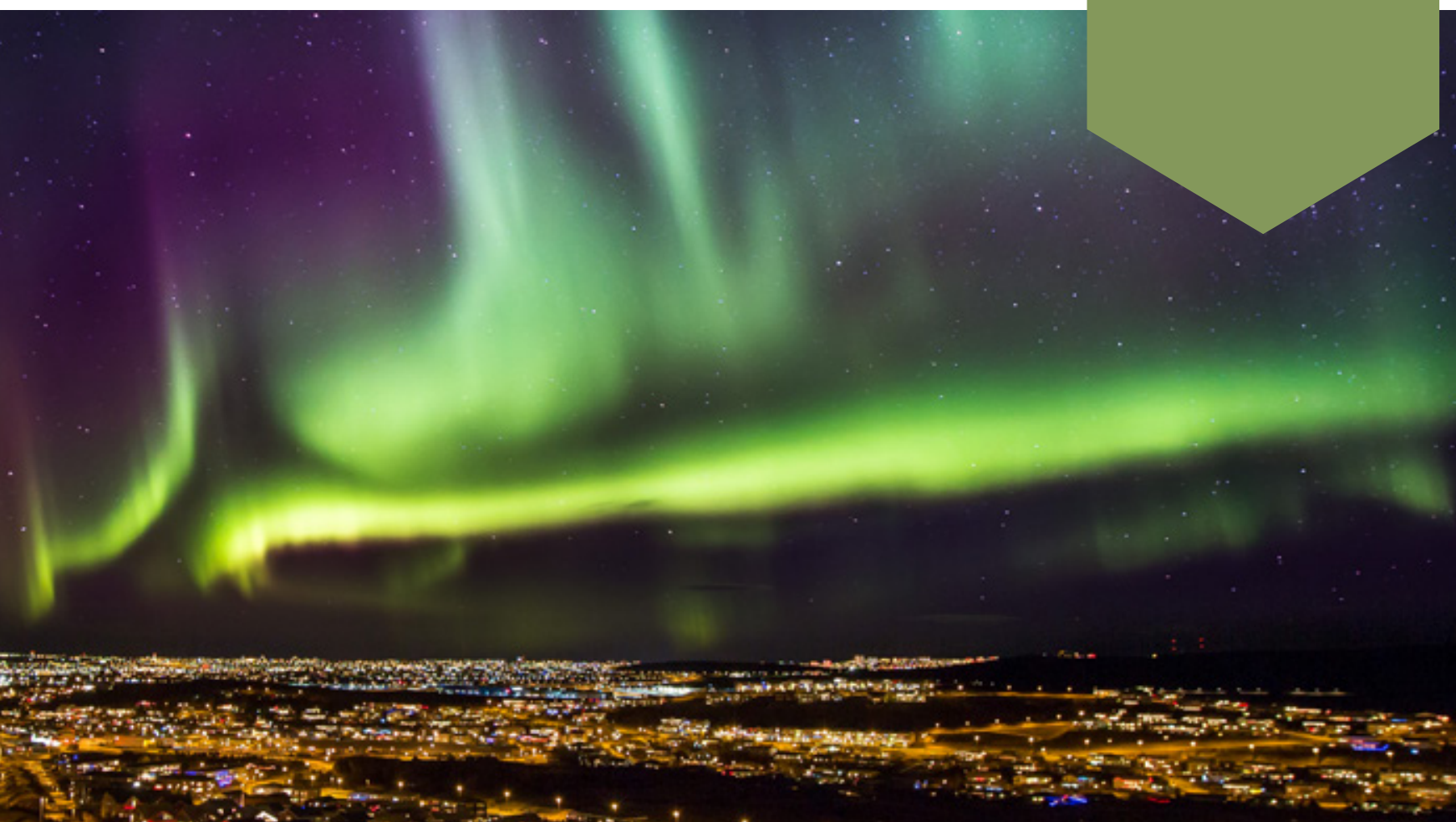
Nordsyn - ecodesign and energy labelling requirements for oil- or gas-fired boilers

ISBN 978-92-893-4380-0 (PRINT)

ISBN 978-92-893-4381-7 (PDF)

http://dx.doi.org/10.6027/ANP2015-788

ANP 2015:788

C Nordic Council of Ministers 2015

Layout: Erling Lynder

Cover photo: Ragnar Th. Sigurdsson/ARCTIC IMAGES

Photos: Signelements

The quality of the tables in this publication is slightly distorted, but based on the best available materials.

This publication has been published with financial support by the Nordic Council of Ministers. However, the contents of this publication do not necessarily reflect the views, policies or recommendations of the Nordic Council of Ministers.

www.norden.org/nordpub
Nordic co-operation

Nordic co-operation is one of the world's most extensive forms of regional collaboration, involving Denmark, Finland, Iceland, Norway, Sweden, and the Faroe Islands, Greenland, and Åland.

Nordic co-operation has firm traditions in politics, the economy, and culture. It plays an important role in European and international collaboration, and aims at creating a strong Nordic community in a strong Europe.

Nordic co-operation seeks to safeguard Nordic and regional interests and principles in the global community. Common Nordic values help the region solidify its position as one of the world's most innovative and competitive.

Nordic Council of Ministers

Ved Stranden 18

DK-1061 Copenhagen K

Phone (+45) 33960200

www.norden.org 


\section{Nordsyn - ecodesign and energy labelling requirements for oil- and gas-fired boilers}

$\begin{array}{ll}\text { Preface } & 4\end{array}$

Summary $\quad 6$

Which products must comply with the requirements? 8

What are the requirements for energy labelling? $\quad 10$

What are the requirements for ecodesign? 14

What are the requirements for documentations? $\quad 16$

Where can I find information? $\quad 18$ 


\section{Preface}

The European Commission published four regulations concerning ecodesign and energy labelling requirements of appliances for space heating and water heating (Regulations: $811 / 2013,812 / 2013,813 / 2013$ and $814 / 2013)$ in the Official Journal 6th of September 2013. The first requirements will apply from 26 September 2015.

In January 2015, the Commission published a guideline on these regulations that contains a section with frequently asked questions (FAQ). Only the regulations are legally binding - the guideline itself is not. However, it is helpful for better understanding the regulations. It is available here: https://ec.europa.eu/energy/ sites/ener/files/documents/ GuidelinesSpaceWaterHeaters_ FINAL.pdf

The Nordic market surveillance authorities have issued a series of fact sheets/guides to help manufacturers and importers of appliances prepare for the new requirements. Four of these fact sheets have been developed by Nordsyn, which is a Nordic cooperation aiming for more efficient market surveillance of ecodesign and energy labelling. Nordsyn's partners are the Swedish Energy Agency/Energimyndigheten, the Danish Energy Agency/ Energistyrelsen, the Finnish Safety and Chemicals Agency/Tukes, the Norwegian Water Resources and Energy Directorate/Norges vassdrags- og Energidirektorat, and the Iceland Construction Authority/Mannvirkjastofnun.

- "Fact sheet on ecodesign and energy labelling requirements for electric heat pumps and electric boilers".

- "Fact sheet on ecodesign and energy labelling requirements for electric heat pump water heaters and electric conventional water heaters".

- "Fact sheet on ecodesign and energy labelling requirements for hot water storage tanks".

- "Fact sheet on energy labelling requirements for packages of water heaters and solar devices".

The Norwegian Water Resources and Energy Directorate (NVE) has also developed two additional fact sheets:

- "Fact sheet on ecodesign and energy labelling requirements for oil- and gas-fired boilers".

- "Fact sheet on energy labelling requirements for packages of space heaters/combination heaters, temperature controls and solar devices".

Together, these fact sheets cover the most common space and water heating appliances on the Nordic market. However, some appliances are not covered by these regulations, e.g. micro CHP appliances and gas-fired water heaters. The individual fact sheets refer to one another when relevant and it is therefore recommended to have them all in order to gain their full benefit. The fact sheets summarise the contents of the Regulations and are addressed to manufacturers, importers and other interested parties. The fact sheets are not legally binding and they do not substitute the Regulations and, in the event of doubt, the Regulations are applicable (any binding interpretation can only be made 
by the EU court). The fact sheets have been developed by Viegand Maagøe A/S, Denmark, as part of Nordsyn and of the Nordic Prime Ministers' overall green growth initiative: The Nordic Region -

leading in green growth under the Nordic Council of Ministers - read more at www.nordicway.org or at www.norden.org/greengrowth

October 2015

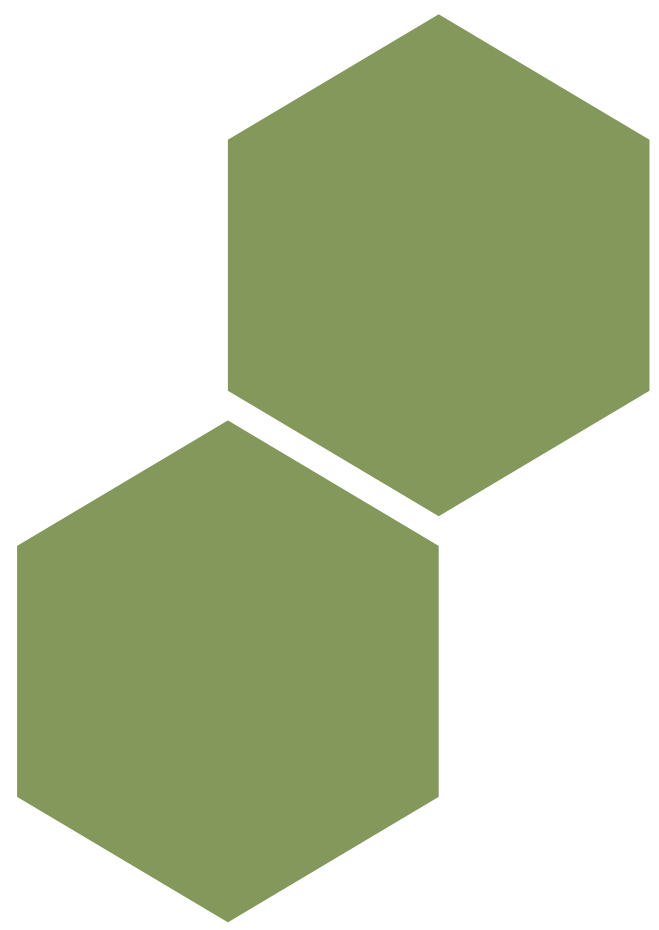




\section{Summary}

\section{Are you a manufacturer or importer of oil- or gas-fired boilers? \\ Please be aware that there are requirements for energy efficiency, $\mathrm{NO}_{\mathrm{x}}$ emissions and energy labelling of oil- or gas-fired boilers.}

Oil- and gas-fired boilers providing heat to a water-based central heating system must meet the ecodesign requirements. This means that the product is designed to meet, for example, minimum energy efficiency requirements.

Oil- and gas-fired boilers must also be energy labelled.

\section{Which products?}

The Ecodesign Regulation applies to:

- Oil- and gas-fired boilers for space heating with a rated output up to and including $400 \mathrm{~kW}$.

- Oil- and gas-fired boilers for combined space and water heating with a rated output up to and including $400 \mathrm{~kW}$.

The Energy Labelling Regulation applies to:
- Oil- and gas-fired boilers for space heating with a rated output up to and including $70 \mathrm{~kW}$.

- Oil- and gas-fired boilers for combined space and water heating with a rated output up to and including $70 \mathrm{~kW}$.

Other products for space and water heating are also covered by the Ecodesign and Energy labelling Regulations.

\section{When?}

The requirements for energy labelling and ecodesign both apply from 26 September 2015.

The ecodesign requirements for oil-and gas-fired boilers include:

- From 26 September 2015 requirements for seasonal space heating energy efficiency for boilers with a rated output up to and including $70 \mathrm{~kW}$.

- From 26 September 2015 requirements for useful efficiency at $100 \%$ and $30 \%$ of the rated output of boilers with a rated output from $70 \mathrm{~kW}$ up to and including $400 \mathrm{~kW}$.
- From 26 September 2015 requirements for water heating energy efficiency for combination boilers. These requirements will be tightened from 26 September 2017.

- From 26 September 2018 emission limits for nitrogen oxides $\left(\mathrm{NO}_{\mathrm{x}}\right)$ in terms of nitrogen dioxide.

- From 26 September 2015 requirements for information on the properties of oil-and gasfired boilers for space heating and combined space and water heating.

The energy labelling regulation for oil-and gas-fired boilers applicable from 26 September 2015 introduce requirements for:

- The provision of a printed EU energy label and a product fiche.

- Information on the product's energy class in advertisements and technical promotion material.

- The provision of electronic versions of the EU energy label and product fiche to dealers for products placed on the market with a new model identifier. 
- The display of the energy label and product fiche when the products are offered for sale through the internet.

\section{Who?}

You are responsible for ensuring and documenting compliance with the requirements if you are:

- A manufacturer in the EEA producing oil- or gas-fired boilers to be placed on the market in the EEA.

- An importer of oil- or gas-fired boilers from a country outside the EEA to be placed on the market in the EEA.

- An authorised representative in the EEA for a manufacturer that is situated in a country outside the EEA.

The responsible parties mentioned above are hereinafter referred to as suppliers.

Dealers of oil and gas boilers are responsible for ensuring that the energy label provided by the supplier is clearly visible on each product at the point of sale.
The EEA (European Economic Area) includes the EU member states and the EFTA counties.

\section{Why?}

Oil- and gas-fired boilers account for a large share of energy consumption in European households. Consequently, the EU has decided to reduce energy consumption of oil- and gas-fired boilers by introducing requirements for energy efficiency and by introducing energy labelling with new energy classes.

\section{Where can I find more information?}

You can find the relevant regulations on the last page of this fact sheet, or read more about ecodesign and energy labelling on the webpages of your market surveillance authorities and the Commission (https://ec.europa.eu/energy/en/topics/energyefficient-products/heaters).

\section{Disclaimer}

This fact sheet presents the contents of the Regulations and is addressed to manufacturers, importers and other interested parties. This fact sheet is not legally binding and does not substitute the Regulations. In the event of doubt, the Regulations are applicable, and any binding interpretation can only be made by the EU court. 


\section{Which products must comply with the requirements?}

From 26 September 2015, the ecodesign requirements will apply to oil and gas boilers with a rated output $\leq 400 \mathrm{~kW}$, and also to any boiler that is part of a package together with other products for space or water heating. The requirements also apply to boilers fired by liquid fossil fuels other than oil, e.g. kerosene.

A distinction is made between heat generators and heater housings. $A$ heat generator is the part of a boiler that produces heat from burning oil or gas (burner). The heater housing is the part designed to be equipped with a heat generator (i.e. the boiler body). A heat generator designed for a heater and a heater housing to be equipped with such a heat generator shall be also considered a heater.

The requirements described in this fact sheet do not apply to:

- Boilers specifically designed to use gaseous or liquid fuels predominantly produced from biomass.

- Boilers within the scope of Directive 2010/75/EU of the
European Parliament and of the Council about industrial emissions.

- Boilers using solid fuels.

- Boilers generating heat only for the purpose of providing hot drinking or sanitary water (these are covered by the requirements for water heaters instead).

- Boilers for heating and distributing gaseous heat transfer media such as vapour or air.

- Boilers designed for heaters and heater housings to be equipped with such heat generators placed on the market before 1 January 2018 to replace identical heat generators and identical heater housings. The replacement product or its packaging must clearly indicate the heater for which it is intended.

The requirements pay particular attention to boilers designed to be connected to a flue shared between multiple dwellings, i.e. so-called B1-boilers.

The requirements for energy labelling of oil-and gas-fired boilers only apply to boilers with a rated output $\leq 70 \mathrm{~kW}$.
A distinction is made between boilers for space heating and combination boilers. In addition to providing space heating, combination boilers must also be designed to provide hot water and to connect to an external water supply. There are additional requirements for combination boilers on ecodesign and energy labelling.

Figure 1 outlines three different types of boiler system: a) is a boiler exclusively for space heating, b) is also characterised as a space heating boiler because it cannot provide domestic hot water or be connected to an external water supply, c) is a combination boiler. There are separate ecodesign and energy labelling requirements for hot water storage tanks, see the "Fact sheet on ecodesign and energy labelling requirements for hot water storage tanks".

Basically, space heating boilers and combination boilers are assumed not to be equipped with temperature controls and solar devices, and the ecodesign and energy labelling requirements are applicable to such individual 
boilers. However, there are also requirements for energy labelling for packages consisting of boilers combined with temperature controllers and/or solar devises.
These requirements are described in the "Fact sheet on energy labelling requirements for packages of space heaters/combination heaters, temperature controls and solar devices".

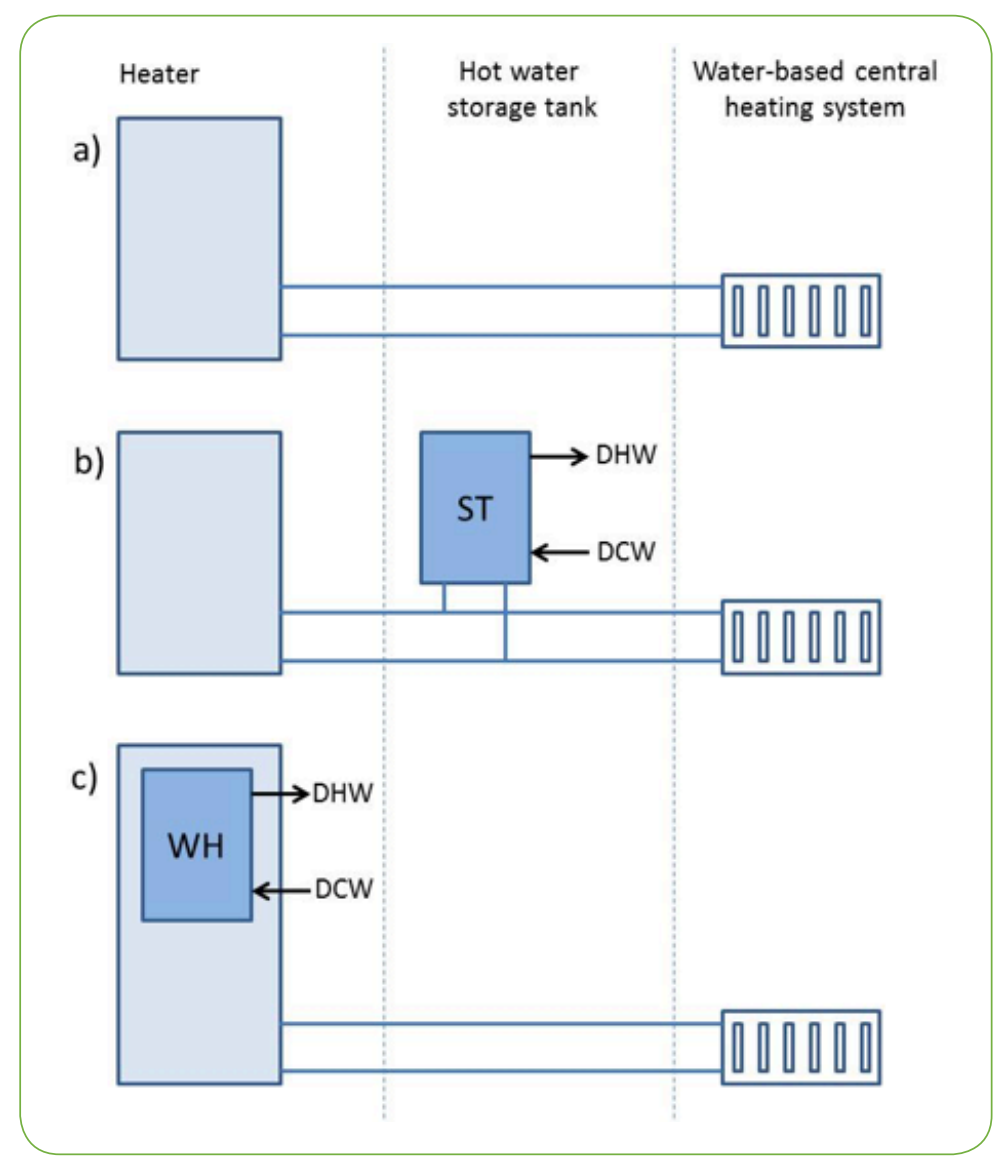

Figure 1: Different types of boiler systems 


\section{What are the requirements for energy labelling?}

From 26 September 2015, oil- and gas-fired boilers must be labelled with the EU energy label. The label is identical in all EU/EEA countries and includes pictograms instead of text, so that the label can be easily understood in all countries.

The label has the recognisable red and green arrows, and the $A-G$ scale is expanded with the energy classes $\mathrm{A}^{+}, \mathrm{A}^{++}$and $\mathrm{A}^{+++}$.

The supplier of the boiler is responsible for providing the energy label together with the boiler.

\section{Energy efficiency classes on the label}

The label for boilers for space heating includes a single scale and the energy classes will be introduced in two stages according to the schedule in Table 1. From 26 September 2015 an energy label with energy classes from $A^{++}$to $G$ is required, and from September 2019 a label with energy classes from $A^{+++}$to $D$ is required.

For combination boilers the label includes two scales. One of the

Table 1: Plan for the introduction of energy classes

\begin{tabular}{lll}
\hline Boiler function & Energy classes & Energy label from \\
\hline Space heating & $\mathrm{A}^{++}-\mathrm{G}$ & 26 September 2015 \\
Space heating & $\mathrm{A}^{++}-\mathrm{D}$ & 26 September 2019 \\
Water heating & $\mathrm{A}-\mathrm{G}$ & 26 September 2015 \\
Water heating & $\mathrm{A}^{+}-\mathrm{F}$ & 26 September 2019 \\
\hline
\end{tabular}

scales is identical with the label for boilers used for space heating, while the other scale covers water heating efficiency and has a different scale of energy classes, as shown in Table 1 . From 26 September 2015 an energy label with energy classes from $A$ to $G$ is required for water heating efficiency, and from 26 September 2019 a label with energy classes from $\mathrm{A}^{+}$to $\mathrm{F}$ is required.

\section{Determination of the energy classes}

The energy label for space heating is based on the seasonal space heating energy efficiency $\left(\eta_{s}\right)$, which is an expression for the delivered heat in relation to the energy input during the heating season. The seasonal space heat- ing energy efficiency is based on an average European climate similar to the climate of Strasbourg.

For oil- and gas-fired boilers, the seasonal space heating energy efficiency is calculated based on results from tests of the boiler's useful efficiency at a rated load and $30 \%$ part load. The calculation also includes corrections for temperature control, boiler electricity consumption (burning, ignition, etc.), standby heat losses and pilot flame (if applicable).

The energy label for water heating is based on water heating energy efficiency $\left(\eta_{w H}\right)$, which is an expression of the supplied hot water in relation to energy input for a given consumption load profile. 
The load profiles are adjusted to various water consumption needs and are described by size categories ranging from XS to XXL. The load profiles are described by a number of "water draw-offs" and the requirements for water temperature and flow are spread over a day from 7:00 a.m. to 10:00 p.m. with defined intervals.
Water heating energy efficiency is calculated on the basis of the test of the combination boiler at a load profile that fits the boiler's hot water production capacity.

All energy input from oil and gas is calculated in relation to the gross calorific value and the power consumption is multiplied by a conversion coefficient $\mathrm{CC}=2.5$, reflecting the power production's estimated average efficiency of $40 \%$ in the EU.

Methods of measurement and calculation of the various factors are described in Regulation EU No 811/2013, Annex VII.

\section{Goss calorific value versus net calorific value}

Traditionally in Europe, energy input from fuels has been related to net calorific value. By changing to gross calorific value, efficiencies in general will seem less as the gross calorific value is approx. $6 \%$ and $10 \%$ higher for oil and gas respectively. For example, an oil-fired boiler with an efficiency of $93 \%$ related to the net calorific value will have an efficiency of $88 \%$ when related to the gross calorific value.

\section{Be aware:}

The actual measurement results without addition of tolerances must be used for declaration of the energy efficiency class and other required declarable values. 


\section{Information on the energy label}

Labels must include information on the boiler's energy class, rated output and noise. In addition, for combination boilers, information on its water heating energy class, load profile and ability to operate only during off-peak operation must be declared. Off-peak operation is when the energy input is provided outside the "water draw-offs" period, i.e. between 10:00 p.m. and 7:00 a.m.
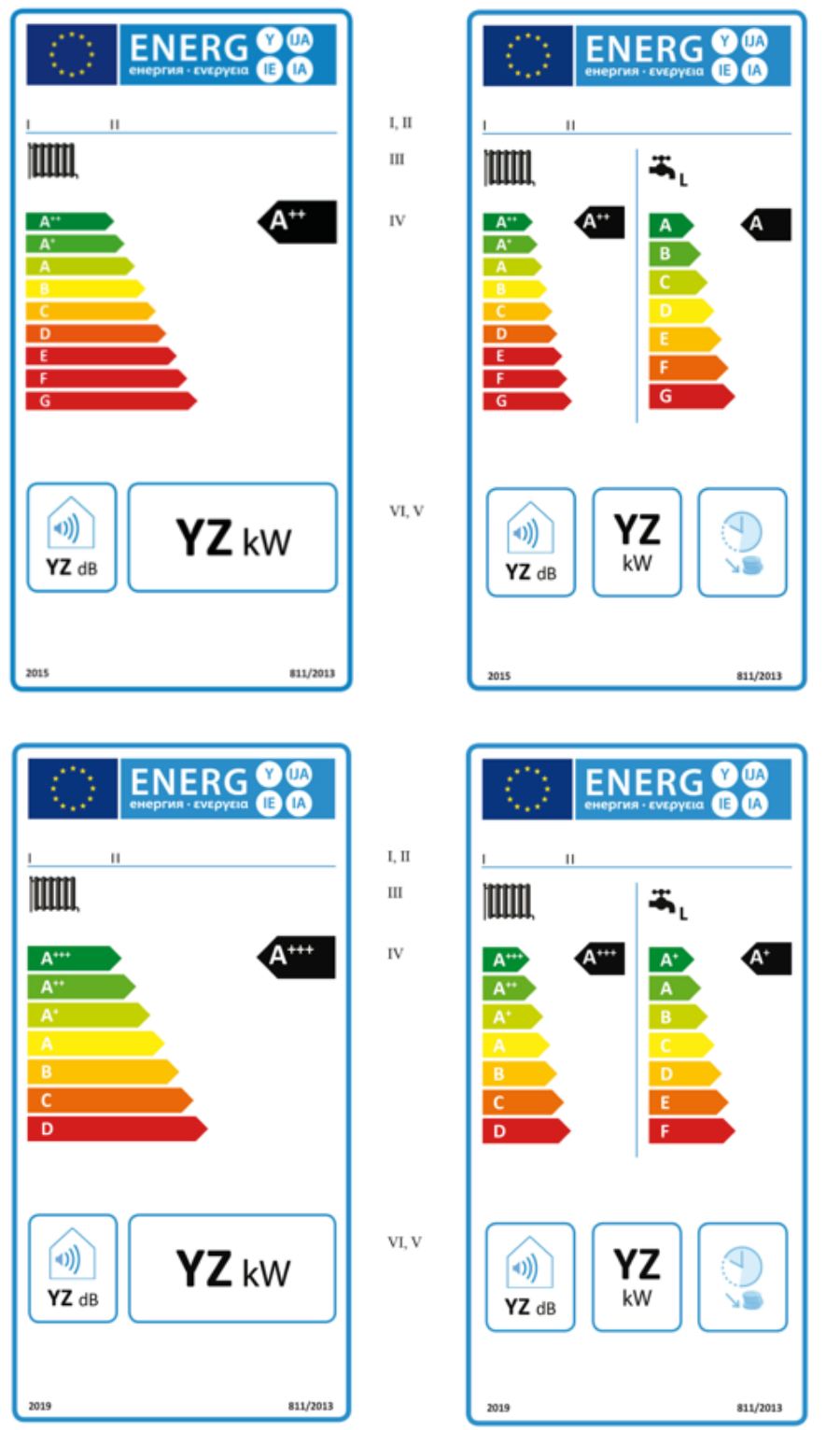


\section{Energy classes}

Table 2 describes the relationship between energy classes and seasonal space heating energy efficiency.

Table 3 describes the relationship between the energy class for a given load profile and energy efficiency for water heating.
Table 2: Energy classes for space heating

\begin{tabular}{|c|c}
\hline Seasonal space heating energy efficiency dass & Seasonal space heating esergy efficiency $\eta_{\mathrm{a}}$ in $*$ \\
\hline $\mathrm{A}^{+++}$ & $\eta_{\mathrm{s}} \geq 150$ \\
\hline $\mathrm{A}^{*+}$ & $125 \leq \eta_{\mathrm{s}}<150$ \\
\hline $\mathrm{A}^{*}$ & $98 \leq \eta_{\mathrm{a}}<125$ \\
\hline $\mathrm{A}$ & $90 \leq \eta_{\mathrm{a}}<98$ \\
\hline $\mathrm{B}$ & $82 \leq \eta_{\mathrm{s}}<90$ \\
\hline $\mathrm{C}$ & $75 \leq \eta_{\mathrm{s}}<82$ \\
\hline $\mathrm{D}$ & $36 \leq \eta_{\mathrm{s}}<75$ \\
\hline $\mathrm{E}$ & $34 \leq \eta_{\mathrm{s}}<36$ \\
\hline $\mathrm{F}$ & $30 \leq \eta_{\mathrm{z}}<34$ \\
\hline $\mathrm{C}$ & $\eta_{\mathrm{s}}<30$ \\
\hline
\end{tabular}

Table 3: Energy classes for water heating

\begin{tabular}{|c|c|c|c|c|c|c|c|c|}
\hline & $3 \mathrm{XS}$ & XXS & XS & $\mathrm{S}$ & M & $\mathrm{L}$ & $\mathrm{XL}$ & XXL \\
\hline $\mathrm{A}^{+++}$ & $\eta_{w h} \geq 62$ & $\eta_{w h} \geq 62$ & $\eta_{w h} \geq 69$ & $\eta_{w h} \geq 90$ & $\eta_{w h} \geq 163$ & $\eta_{w h} \geq 188$ & $\eta_{w h} \geq 200$ & $\eta_{w h} \geq 213$ \\
\hline $\mathrm{A}^{++}$ & $\begin{array}{c}53 \leq \eta_{w h} \\
<62\end{array}$ & $\begin{array}{c}53 \leq \eta_{w h} \\
<62\end{array}$ & $\begin{array}{c}61 \leq \eta_{w h} \\
<69\end{array}$ & $\begin{array}{c}72 \leq \eta_{w h} \\
<90\end{array}$ & $\begin{array}{c}130 \leq \eta_{w h} \\
<16 / 3\end{array}$ & $\begin{array}{c}150 \leq \eta_{w h} \\
<188\end{array}$ & $\begin{array}{c}160 \leq \eta_{w h} \\
<200\end{array}$ & $\begin{array}{c}170 \leq \eta_{w h} \\
<213\end{array}$ \\
\hline $\mathrm{A}^{+}$ & $\begin{array}{c}44 \leq \eta_{w h} \\
<53\end{array}$ & $\begin{array}{c}44 \leq \eta_{w h} \\
<53\end{array}$ & $\begin{array}{c}53 \leq \eta_{w h} \\
<61\end{array}$ & $\begin{array}{c}55 \leq \eta_{w h} \\
<72\end{array}$ & $\begin{array}{c}100 \leq \eta_{w h} \\
<130\end{array}$ & $\begin{array}{c}115 \leq \eta_{w h} \\
<150\end{array}$ & $\begin{array}{c}123 \leq \eta_{w h} \\
<160\end{array}$ & $\begin{array}{c}131 \leq \eta_{w h} \\
<170\end{array}$ \\
\hline A & $\begin{array}{c}35 \leq \eta_{w h} \\
<44\end{array}$ & $\begin{array}{c}35 \leq \eta_{w h} \\
<44\end{array}$ & $\begin{array}{c}38 \leq \eta_{w h} \\
<53\end{array}$ & $\begin{array}{c}38 \leq \eta_{w h} \\
<55\end{array}$ & $\begin{array}{c}65 \leq \eta_{w h} \\
<100\end{array}$ & $\begin{array}{c}75 \leq \eta_{w h} \\
<115\end{array}$ & $\begin{array}{c}80 \leq \eta_{w h} \\
<123\end{array}$ & $\begin{array}{c}85 \leq \eta_{\text {wh }} \\
<131\end{array}$ \\
\hline B & $\begin{array}{c}32 \leq \eta_{w h} \\
<35\end{array}$ & $\begin{array}{c}32 \leq \eta_{w h} \\
<35\end{array}$ & $\begin{array}{c}35 \leq \eta_{w h} \\
<38\end{array}$ & $\begin{array}{c}35 \leq \eta_{w h} \\
<38\end{array}$ & $\begin{array}{c}39 \leq \eta_{w h} \\
<65\end{array}$ & $\begin{array}{c}50 \leq \eta_{w h} \\
<75\end{array}$ & $\begin{array}{c}55 \leq \eta_{w h} \\
<80\end{array}$ & $\begin{array}{c}60 \leq \eta_{w h} \\
<85\end{array}$ \\
\hline $\mathrm{C}$ & $\begin{array}{c}29 \leq \eta_{w h} \\
<32\end{array}$ & $\begin{array}{c}29 \leq \eta_{w h} \\
<32\end{array}$ & $\begin{array}{c}32 \leq \eta_{w h} \\
<35\end{array}$ & $\begin{array}{c}32 \leq \eta_{w h} \\
<35\end{array}$ & $\begin{array}{c}36 \leq \eta_{w h} \\
<39\end{array}$ & $\begin{array}{c}37 \leq \eta_{w h} \\
<50\end{array}$ & $\begin{array}{c}38 \leq \eta_{w h} \\
<55\end{array}$ & $\begin{array}{c}40 \leq \eta_{w h} \\
<60\end{array}$ \\
\hline $\mathrm{D}$ & $\begin{array}{c}26 \leq \eta_{w h} \\
<29\end{array}$ & $\begin{array}{c}26 \leq \eta_{w h} \\
<29\end{array}$ & $\begin{array}{c}29 \leq \eta_{w h} \\
<32\end{array}$ & $\begin{array}{c}29 \leq \eta_{w h} \\
<32\end{array}$ & $\begin{array}{c}33 \leq \eta_{w h} \\
<36\end{array}$ & $\begin{array}{c}34 \leq \eta_{w h} \\
<37\end{array}$ & $\begin{array}{c}35 \leq \eta_{w h} \\
<38\end{array}$ & $\begin{array}{c}36 \leq \eta_{w h} \\
<40\end{array}$ \\
\hline $\mathrm{E}$ & $\begin{array}{c}22 \leq \eta_{w h} \\
<26\end{array}$ & $\begin{array}{c}23 \leq \eta_{w h} \\
<26\end{array}$ & $\begin{array}{c}26 \leq \eta_{w h} \\
<29\end{array}$ & $\begin{array}{c}26 \leq \eta_{w h} \\
<29\end{array}$ & $\begin{array}{c}30 \leq \eta_{w h} \\
<33\end{array}$ & $\begin{array}{c}30 \leq \eta_{w h} \\
<34\end{array}$ & $\begin{array}{c}30 \leq \eta_{w h} \\
<35\end{array}$ & $\begin{array}{c}32 \leq \eta_{w h} \\
<36\end{array}$ \\
\hline $\mathrm{F}$ & $\begin{array}{c}19 \leq \eta_{w h} \\
<22\end{array}$ & $\begin{array}{c}20 \leq \eta_{w h} \\
<23\end{array}$ & $\begin{array}{c}23 \leq \eta_{w h} \\
<26\end{array}$ & $\begin{array}{c}23 \leq \eta_{w h} \\
<26\end{array}$ & $\begin{aligned} 27 & \leq \eta_{w h} \\
& <30\end{aligned}$ & $\begin{array}{c}27 \leq \eta_{w h} \\
<30\end{array}$ & $\begin{array}{c}27 \leq \eta_{w h} \\
<30\end{array}$ & $\begin{array}{c}28 \leq \eta_{w h} \\
<32\end{array}$ \\
\hline G & $\eta_{w h}<19$ & $\eta_{w h}<20$ & $\eta_{w h}<23$ & $\eta_{w h}<23$ & $\eta_{w h}<27$ & $\eta_{w h}<27$ & $\eta_{w h}<27$ & $\eta_{w h}<28$ \\
\hline
\end{tabular}




\section{What are the requirements for ecodesign?}

From 26 September 2015 oil- and gas-fired boilers must meet minimum requirements for seasonal space heating energy efficiency/ useful efficiency for space heating. In addition, combination boilers must meet the minimum requirements for water heating efficiency. From 26 September 2018 the maximum requirements for $\mathrm{NO}_{\mathrm{x}}$ emissions must also be met.

The minimum requirements for seasonal space heating energy efficiency/useful efficiency, water heating efficiency and $\mathrm{NO}_{x}$ emissions are related to gross calorific value just as for energy labelling.

\section{Requirements for seasonal space heating energy efficiency}

Oil- and gas-fired boilers for space heating and combination boilers with a rated output $\leq 70 \mathrm{~kW}$ must meet the requirements for seasonal space heating energy efficiency listed in Table 4.

The requirements imply that all oil- and gas-fired boilers must be condensing, with the exemption of

Table 4: Requirements for seasonal space heating energy efficiency. The seasonal space heating energy efficiency must meet the minimum requirements listed in the table

\begin{tabular}{ll}
\hline Boiler type & $\begin{array}{l}\text { Requirements for seasonal space } \\
\text { heating energy efficiency }\end{array}$ \\
\hline Space heating boiler & $\geq 86 \%$ \\
Combination boiler & $\geq 86 \%$ \\
$\begin{array}{l}\text { Exemption: Type B1 boiler with a } \\
\text { rated output } \leq 10 \mathrm{~kW}\end{array}$ & $\geq 75 \%$ \\
$\begin{array}{l}\text { Exemption: } \text { Type B1 combination } \\
\text { boiler with a rated output } \leq 30 \mathrm{~kW}\end{array}$ & $\geq 75 \%$ \\
\hline
\end{tabular}

the special type B1 boilers, which are designed to be connected to a flue shared between multiple dwellings. This exemption is limited to the maximum rated output for this boiler type specified in Table 4 .

\section{Requirements for useful efficiency}

Oil and gas boilers with a rated output between $>70 \mathrm{~kW}$ and $\leq 400$ $\mathrm{kW}$ must meet the requirements of a useful efficiency at full load of at least $86 \%$ and a useful efficiency at $30 \%$ part load of at least $94 \%$.
The result of these requirements is that only condensing boilers will be allowed.

\section{Requirements for water heating efficiency}

The minimum requirements for water heating energy efficiency for combination boilers will be introduced in two stages. Table 5 shows the minimum requirements from 26 September 2015 and the tightened requirements from 26 September 2017. 
Table 5: Requirements for water heating energy efficiency. Water heating energy efficiency must meet the requirements shown in the table

\begin{tabular}{l|c|c|c|c|c|c|c|c|c|c}
\hline Declared load profile & 3XS & XXS & XS & S & M & L & XL & XXL & 3XL & 4XL \\
\hline $\begin{array}{l}\text { Water heating } \\
\text { energy efficiency }\end{array}$ & $22 \%$ & $23 \%$ & $26 \%$ & $26 \%$ & $30 \%$ & $30 \%$ & $30 \%$ & $32 \%$ & $32 \%$ & $32 \%$ \\
\hline
\end{tabular}

\begin{tabular}{l|c|c|c|c|c|c|c|c|c|c}
\hline Declared load profile & $3 \mathrm{XS}$ & $\mathrm{XXS}$ & $\mathrm{XS}$ & $\mathrm{S}$ & $\mathrm{M}$ & $\mathrm{L}$ & $\mathrm{XL}$ & $\mathrm{XXL}$ & $3 \mathrm{XL}$ & 4XL \\
\hline $\begin{array}{l}\text { Water heating } \\
\text { energy efficiency }\end{array}$ & $32 \%$ & $32 \%$ & $32 \%$ & $32 \%$ & $36 \%$ & $37 \%$ & $38 \%$ & $60 \%$ & $64 \%$ & $64 \%$ \\
\hline
\end{tabular}

Requirements for $\mathrm{NO}_{x}$ emissions From 26 September $2018 \mathrm{NO}_{x}$ emissions expressed as $\mathrm{NO}_{2}$ and related to fuel consumption on the basis of gross calorific value must not exceed the values in Table 6.

\section{Miscellaneous}

The measurement and calculation methods are identical to the ones used for energy labelling.

In addition, a heat generator designed for a boiler and a boiler housing to be equipped with such a heat generator must be tested with an appropriate boiler housing and heat generator, respectively.

Table 6: Requirements for $\mathrm{NO}_{x}$ emissions. $\mathrm{NO}_{x}$ emissions must not exceed the values shown in the table

\begin{tabular}{lll}
\hline Boiler type & Fuel & NO emissions \\
\hline Space heating boiler & Gaseous & $\leq 56 \mathrm{mg} / \mathrm{kWh}$ \\
Combination boiler & Gaseous & $\leq 56 \mathrm{mg} / \mathrm{kWh}$ \\
Space heating boiler & Liquid & $\leq 120 \mathrm{mg} / \mathrm{kWh}$ \\
Combination boiler & Liquid & $\leq 120 \mathrm{mg} / \mathrm{kWh}$ \\
\hline
\end{tabular}




\section{What are the requirements for information and documentation?}

\section{Energy labelling}

\section{Energy label and product fiche}

All oil- and gas-fired boilers for space heating or combination boilers placed on the market from 26 September 2015 must be provided with a printed energy label and a product fiche. A product fiche may include several models of boilers for space heating from the same supplier. See the guidelines for product fiches in the Regulation on Energy Labelling, Annex IV.

Furthermore, electronic versions of the energy label and the product fiche must be made available to dealers for products placed on the market with a new model identifier. The layout of the electronic energy label must be identical to the printed label, and the electronic versions of the label and the fiche must include the same information as the printed versions.

\section{Information in technical promotional material and in advertisements}

Relevant technical promotion material and advertisements for boilers shall include information on the energy class of the boiler. Further information is available in Regulation 811/2013/EU, Article 3 and 4.

\section{Labelling on the internet}

The electronic energy label and product fiche must be shown on the display in proximity to the price when heat pumps and electric boilers are offered for sale or hire through the internet. The label and the product fiche may be shown using a "nested display".

\section{Ecodesign}

\section{CE marking and EC declaration of conformity}

Boilers covered by the ecodesign requirements must be $\mathrm{CE}$ marked when they are placed on market in the EEA countries.

Furthermore, an EC declaration of conformity must be made available by the supplier. In the EC declaration of conformity, the manufacturer or its authorised representative in the EEA must document and guarantee that their boilers comply with all relevant
EU regulations. Consequently, the reference number of the Ecodesign Regulation 813/2013/EU must be mentioned in the declaration of conformity.

You can find the requirements for the contents of an EC declaration of conformity in the Ecodesign Directive 2009/125/EC Annex VI.

\section{Ecodesign and energy labelling}

\section{Technical documentation}

The supplier is responsible for making sure that there is technical documentation for the boiler when it is placed on the EEA market. The technical documentation must show that the boiler is constructed in conformity with the ecodesign requirements and that the energy labelling of the boiler is correct. The technical documentation must be compiled by the manufacturer.

For boilers, you can find the requirements for technical documentation and information to be made available on the manufacturer's website in 
Regulation 813/2013/EU Annex II, point 5 and in Regulation 811/2013/EU Annex V.

The market surveillance authorities of the EEA countries may request the technical documentation, and you must provide it within a maximum of ten days after receiving the request.

The documentation relating to ecodesign requirements must be stored for a period of ten years after the last model of that product has been manufactured. In the case of energy labelling requirements, the documentation must be stored for five years.

\section{Measurement and calculation methods}

Reliable, accurate and reproducible measurement methods based on generally accepted measurement techniques must be used. $A$ reproducible measurement method means that the measurements can be repeated with the same result. The technical documentation must be based on a third party testing of oil- and gasfired boilers as the relevant clauses about this in the Boiler Directive 92/42/EC are retained. In all other respects Regulation EU No 813/2013 replaces the Boiler Directive.

The measurements must always be carried out in accordance with the Regulations. 


\section{Where can I find information?}

The webpages of the national market surveillance authorities and the Commission (https://ec.europa. eu/energy/en/topics/energyefficient-products/heaters) contain more information about policies, new regulatory requirements, guidance, contact information, and links to relevant legislation.

\section{Legislation}

\section{COMMISSION REGULATION}

(EU) No 813/2013 of 2 August 2013 implementing Directive 2009/125/EC of the European Parliament and of the Council with regard to ecodesign requirements for space heaters and combination heaters.

\section{DIRECTIVE 2009/125/EC OF THE} EUROPEAN PARLIAMENT AND OF THE COUNCIL of 21 October 2009 establishing a framework for the setting of ecodesign requirements for energy-related products (recast).

\section{COMMISSION DELEGATED}

REGULATION (EU) No 811/2013

of 18 February 2013 supple- menting Directive 2010/30/EU

of the European Parliament and of the Council with regard to the energy labelling of space heaters, combination heaters, packages of space heater, temperature control and solar devices, and packages of combination heater, temperature control and solar devices.

\section{DIRECTIVE 2010/30/EU OF THE} EUROPEAN PARLIAMENT AND OF THE COUNCIL of 19 May 2010 on the indication by labelling and standard product information of the consumption of energy and other resources by energy-related products (recast).

COMMISSION DELEGATED REGULATION (EU) No518/2014 of 5 March 2014 amending Commission Delegated Regulations (EU) No 1059/2010, (EU) No 1060/2010, (EU) No 1061/2010, (EU) No 1062/2010, (EU) No 626/2011, (EU) No 392/2012, (EU) No 874/2012, (EU) No 665/2013, (EU) No $811 / 2013$ and (EU) No 812/2013 with regard to labelling of energy-related products on the internet.

\section{Where can I find help and guidance?}

You can get help to understand the requirements and answers to your questions by contacting your national market surveillance authority for ecodesign and energy labelling. 
<smiles>C1CC[C@H]2CCCC[C@@H]2CC1</smiles> 


\section{norden}

Nordic Council of Ministers

Ved Stranden 18

DK-1061 Copenhagen K

www.norden.org

ANP 2015:788

ISBN 978-92-893-4380-0 (PRINT)

ISBN 978-92-893-4381-7 (PDF) 